\title{
A model for the growth of mariculture kelp Saccharina japonica in Sanggou Bay, China
}

\author{
Jihong Zhang ${ }^{1,2, *}$, Wenguang $\mathrm{Wu}^{1}$, Jeffrey S. $\operatorname{Ren}^{3}$, Fan $\operatorname{Lin}^{1}$ \\ ${ }^{1}$ Yellow Sea Fisheries Research Institute, Chinese Academy of Fishery Sciences, Qingdao 266071, PR China \\ ${ }^{2}$ Function Laboratory for Marine Fisheries Science and Food Production Processes, \\ Qingdao National Laboratory for Marine Science and Technology, Qingdao, PR China \\ ${ }^{3}$ National Institute of Water and Atmospheric Research, 10 Kyle Street, PO Box 8602, Christchurch 8440, New Zealand
}

\begin{abstract}
The kelp Saccharina japonica is one of the most important mariculture species in China. To predict kelp growth and provide a component for a general multitrophic ecosystem model, a dynamic individual growth model was developed to evaluate environmental effects on kelp growth. This model was calibrated and validated using data from 2 annual mariculture cycles (2008-2009, 2011-2012) from Sanggou Bay, China. Gross growth of S. japonica was described as functions of temperature, light and nutrient contents in plant tissues (internal nutrients), and nitrogen $(\mathrm{N})$ and phosphorus $(\mathrm{P})$ in seawater. Net growth was defined as gross growth minus respiration. The simulation results showed that nutrients were the key limiting factor for growth throughout the kelp growth cycle, whereas both temperature and light only limited kelp growth during simulation days 60-120, i.e. from 1 January to the end of February. Scenario simulations showed that fertilizing with nitrogen could improve kelp growth by as much as 4.4 times. The model also predicted that individual dry weight of $S$. japonica would increase by $18 \%$ when lifting the culture ropes up to the surface. Sensitivity analysis indicates that the empirical coefficient of respiration $(r)$, maximum growth rate $\left(\mu_{\max }\right)$ and minimum internal quota for nitrogen $\left(N_{\mathrm{imin}}\right)$ were among the most sensitive parameters. This model shows that the introduction of culture methods such as cage culture, which allows more effective fertilization and depth control, would result in more effective kelp farming.
\end{abstract}

KEY WORDS: Kelp · Saccharina japonica · Suspended long-line culture $\cdot$ Environmental variables · Individual growth model $\cdot$ Sanggou Bay

\section{INTRODUCTION}

The kelp Saccharina japonica (previously Laminaria japonica) is one of the most intensively cultured seaweed species in the world. The annual production of this species was $~ 5.09$ million $t$ in China in 2013 (FAO 2014). For management of kelp mariculture, it is important to understand the environmental effects on growth and production and to be able to estimate the carrying capacity of the culture ecosystems (Liu et al. 2013).

Large-scale seaweed cultivation has been proposed as a method for mitigating eutrophication in

\footnotetext{
*Corresponding author: zhangjh@ysfri.ac.cn
}

coastal ecosystems (Fei 2004). Co-culture of kelp with other species in integrated multi-trophic aquaculture (IMTA) systems has been shown to improve water quality, daylight oxygen levels were reported to have increased and excreted nutrients decreased (Chopin et al. 2001, Troellet al. 2003, Buschmannet al. 2008). A model of the physiological behaviour and growth of kelp would be an important contribution to a general IMTA model which could be used in optimising production of each trophic species in IMTA systems.

Macroalgal growth modelling is a powerful tool and is being increasingly used in sustainable man-

(C) The authors 2016. Open Access under Creative Commons by Attribution Licence. Use, distribution and reproduction are unrestricted. Authors and original publication must be credited. 
agement of coasts and estuaries (Duarte et al. 2003, Aveytua-Alcázar et al. 2008), as a component of ecosystem models to estimate carrying capacity of polyculture ecosystems (Duarte et al. 2003, Nuneset al. 2003, Shi et al. 2011). However, the application of these sub-models of kelp is limited because they are over-simplified and do not consider all the key limiting factors, particularly the effect of the internal state on growth. The recent development of a green-algal model is probably the most comprehensive macroalgal model (Ren et al. 2014) in which most of these factors have been incorporated. To our knowledge, there are no similar models available as yet for kelp.

The objective of this study was to develop a generic growth model of kelp for predicting its response to dynamic environmental conditions, to understand the relationship between potential increases in production and environmental fertilization, and to investigate the effects of climate change (temperature increase) on mariculture. The main purpose of the model is to guide maricultural activity. Fertilization (by the hanging bag method) and adjusting culture depth are the most commonly used techniques in kelp mariculture in China. Using these techniques, the cultivation efficiency can be assessed by comparison with the model prediction.

\section{MATERIALS AND METHODS}

\section{Study area}

The growth model was developed for Sanggou Bay, which is located at the eastern end of Shandong Peninsula, PR China $\left(37^{\circ} 01-09 \mathrm{~N}, 122^{\circ} 24-35 \mathrm{E}\right)$ (Fig. 1). The total area is $140 \mathrm{~km}^{2}$, with an average depth of $7.5 \mathrm{~m}$. The tidal elevation in Sanggou Bay is irregularly semidiurnal with a maximum tidal range of $\sim 2 \mathrm{~m}$. The flooding tide current enters the bay along the northern side, flows anti-clockwise and exits along the southern side; the ebbing tide is in the opposite direction (Shi et al. 2011). There are several seasonal stream rivers for freshwater input to Sanggou Bay, with runoff (approx. 1.7-2.3 $\times 10^{8} \mathrm{~m}^{3}$ ) accounting for ca. $17 \%$ of the total volume of the bay (Li et al. 2014). Temperature ranges from 2 to $26^{\circ} \mathrm{C}$ and average salinity is $30.6 \%$. The bay is one of the most intensively cultured bays in China and aquaculture was already introduced in the 1980s. The main cultivated species are kelp (Saccharina japonica), scallop (Chlamys farreri) and Pacific oyster Crassostrea gigas. Annual production of kelp is 68000 t in dry weight. Kelp occurs mainly near the mouth of the bay as a monoculture and integrates with bivalves towards the middle of the bay. Kelp is typically cultivated from November to the end of May in the following year. The sample site was in the northern Sanggou Bay.

\section{Available data and data analysis}

Field data were obtained during 2 mariculture cycles of $S$. japonica at the experimental site in Sanggou Bay (Fig. 1B), from November to May for the years 2008-2009 and 2011-2012. Length and dry weight of kelp fronds were measured twice each month, while environmental parameters were measured monthly, including water temperature, salinity, total suspended particulate materials and nutrient concentrations. Total suspended matter concentrations were obtained by filtering a known volume of water onto a preweighed and pre-dried $\left(450^{\circ} \mathrm{C}, 5 \mathrm{~h}\right)$ Whatman $\mathrm{GF} / \mathrm{F}$ glass fiber filter. The filter was then oven-dried at $60^{\circ} \mathrm{C}$ for $24 \mathrm{~h}$ and total suspended solids were calcu-
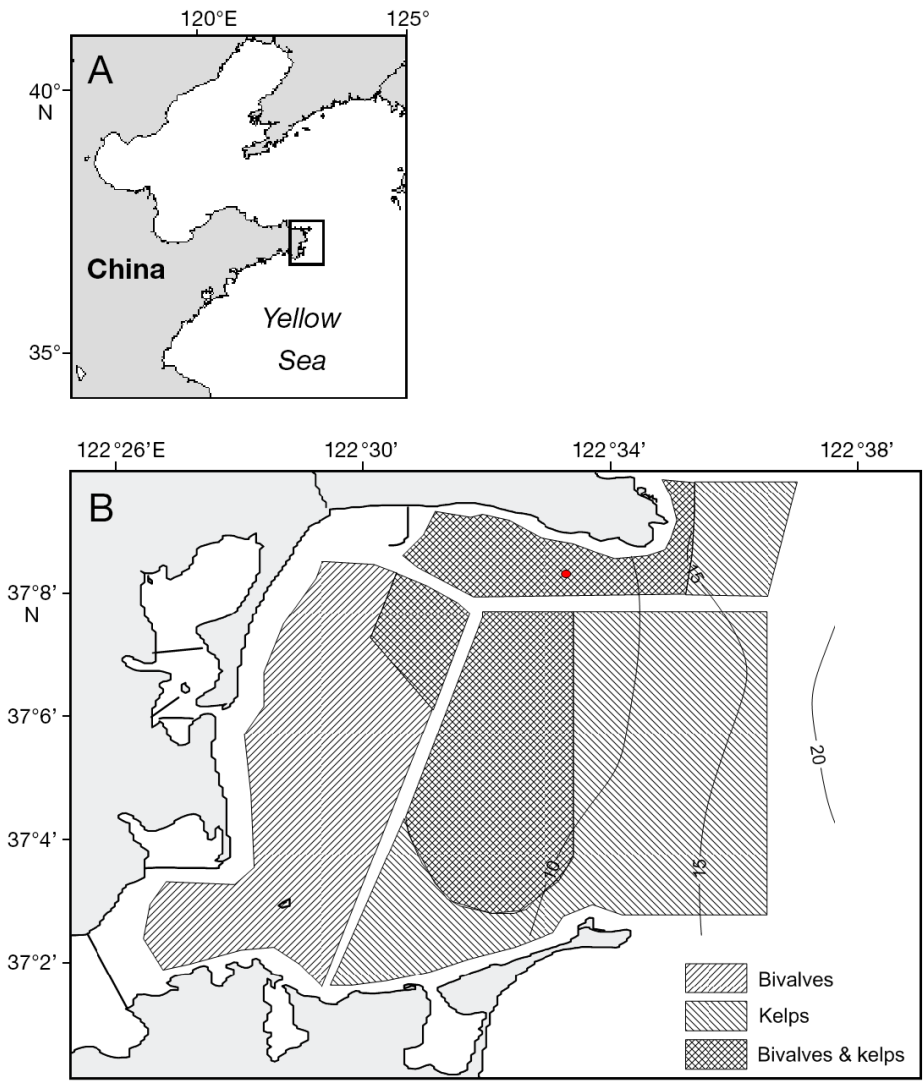

Fig. 1. (A) Location of Sanggou Bay (rectangle) at the eastern end of Shandong Peninsula, China and (B) location of the experimental site (red dot) in the northern part of the bay, within the kelp and bivalve mariculture area. Areas of kelp or bivalve monoculture are also indicated. Contour lines: 10, 15 and $20 \mathrm{~m}$ water depth 
lated. Dissolved inorganic nitrogen (i.e. $\mathrm{NH}_{4}-\mathrm{N}+$ $\mathrm{NO}_{3}-\mathrm{N}+\mathrm{NO}_{2}-\mathrm{N}$, hereafter called $\mathrm{N}$ ), and phosphorus (i.e. $\mathrm{PO}_{4}-\mathrm{P}$, hereafter called $\mathrm{P}$ ) were analyzed with colorimetric methods (Grasshoff et al. 1983).

\section{Model description}

A conceptual diagram of the model is depicted in Fig. 2. The equations for the main parameters are presented below. The environmental variables influencing the growth of kelp in the present model are temperature $(T)$, irradiance $(I)$ and nutrient concentration $(N$ and/or $P$ ) in the water. The model was run with STELLA 9.1.3 software using a time step of $1 \mathrm{~d}$ for $180 \mathrm{~d}$, which started from the beginning of November to May, corresponding to culture day 1 through 180.

\section{Main processes and state variables}

Kelp biomass can be defined as a balance between 2 dynamic processes: gross macroalgal production (growth) and removal of macroalgal biomass by respiration and erosion, or 'apical frond loss'. The biomass of $\operatorname{kelp}\left(B, \mathrm{~g}\right.$ dry weight [DW] ind. $\left.{ }^{-1}\right)$ is governed by the following equation:

$$
\frac{\mathrm{d} B}{\mathrm{~d} t}=(\mathrm{NGR}-\mathrm{ER}) \times B
$$

where NGR is the net growth rate $\left(\mathrm{d}^{-1}\right)$, ER is the individual erosion rate $\left(\mathrm{d}^{-1}\right)$ per kelp and $t$ is time $(\mathrm{d})$.

NGR is defined by the difference between gross growth rate $\left(G_{\text {growth }}, \mathrm{d}^{-1}\right)$ and respiration rate $\left(R_{\text {esp }}, \mathrm{d}^{-1}\right)$ :

$$
\mathrm{NGR}=G_{\text {growth }}-R_{\text {esp }}
$$
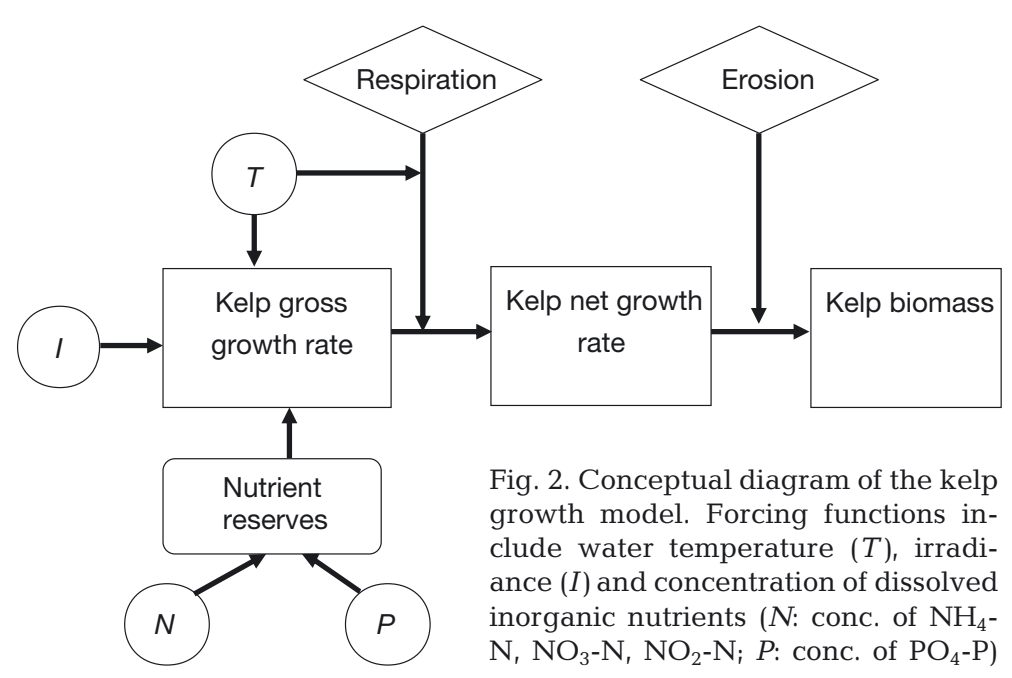

Fig. 2. Conceptual diagram of the kelp growth model. Forcing functions include water temperature $(T)$, irradiance $(I)$ and concentration of dissolved inorganic nutrients ( $N$ : conc. of $\mathrm{NH}_{4}^{-}$ $\mathrm{N}, \mathrm{NO}_{3}-\mathrm{N}, \mathrm{NO}_{2}-\mathrm{N}_{i} P$ : conc. of $\mathrm{PO}_{4}-\mathrm{P}$ )
It is generally accepted that respiration, like any other biochemical reaction, is temperature dependent and can be described by an Arrhenius function (Duarte \& Ferreira 1997, Martins \& Marques 2002):

$$
R_{\mathrm{esp}}=R_{\max 20} \times r^{\left(T_{\mathrm{w}}-20\right)}
$$

where $R_{\max 20}$ is the maximum respiration rate at $20^{\circ} \mathrm{C}, r$ is the empirical coefficient and $T_{\mathrm{w}}$ is seawater temperature $\left({ }^{\circ} \mathrm{C}\right)$.

$G_{\text {growth }}$ is described as a function of water temperature, irradiance and internal concentration of nutrients (NP) (Solidoro et al. 1997, Duarte \& Ferreira 1997, Martins \& Marques 2002), with $\mu_{\max }$ being the maximum growth rate:

$$
G_{\text {growth }}=\mu_{\max } \times f(T) \times f(N P) \times f(I)
$$

Kelp growth depends on temperature, which is described by a temperature-optimum curve (Duarte et al. 2003). The temperature limitation is expressed as follows:

$$
f(T)=\frac{2.0(1+\beta) \times X_{T}}{X_{T}^{2}+2.0 \times \beta \times X_{T}+1.0}
$$

where $X_{T}=\frac{T_{\mathrm{w}}-T_{\mathrm{opt}}}{T_{\mathrm{opt}}-T_{\max }}, T_{\max }$ is the upper temperature limit above which growth ceases $\left({ }^{\circ} \mathrm{C}\right), T_{\text {opt }}$ is the optimum temperature for growth $\left({ }^{\circ} \mathrm{C}\right)$, and $\beta$ is an adjustment parameter $\left({ }^{\circ} \mathrm{C}\right)$.

Light attenuation through a column of water is one of the primary limiting variables in the growth of macroalgae. Kelp production is limited by light intensity. Similar to Shi et al. (2011), the functional response is integrated over depth:

$$
f(I)=\frac{I}{I_{\mathrm{o}}} \times \mathrm{e}^{\left(1-\frac{I}{I_{0}}\right)}
$$

where $I_{0}$ is the optimum light intensity for growth $\left(\mathrm{W} \mathrm{m}^{-2}\right)$ and $I$ is the light intensity at depth $Z$ defined by the Lambert-Beer law:

$$
I=I_{\mathrm{s}} \times \mathrm{e}^{-k \mathrm{Z}}
$$

where $k$ is the coefficient of light attenuation $\left(\mathrm{m}^{-1}\right), Z$ is the depth of kelp mariculture $(\mathrm{m})$ and $I_{\mathrm{s}}$ is the light intensity at the surface $\left(\mathrm{W} \mathrm{m}^{-2}\right)$, expressed by the following cosine function of time, which is based on Shi et al. (2011):

$$
I_{\mathrm{s}}=200.38-116.47 \times \cos [2 \pi(t-1) / 365]
$$

The light extinction coefficient $\left(k, \mathrm{~m}^{-1}\right)$ is influenced by suspended particles in 
the water column. The suspended particles include many different forms such as phytoplankton, and particulate organic and inorganic matter. The $k$ value depends on the type of the particles (Parsons et al. 1984). For simplicity, $k$ was calculated from an empirical relationship with total particulate matter (TPM; the concentration of total suspended particulate materials, $\mathrm{mg} \mathrm{l}^{-1}$ ) (Duarte et al. 2003):

$$
k=0.0484 \mathrm{TPM}+0.0243
$$

Similar to most macroalgae, kelp store nutrients ( $\mathrm{N}$ and $\mathrm{P}$ ) in the tissue for growth, thus buffering the kelp against external nutrient shortage (Chapman \& Craigie 1977, Pedersen \& Borum 1996). Growth and photosynthesis are directly dependent on internal rather than external nutrient concentrations. Therefore, the model considers kelp growth to be a function of internal concentration of nutrients (NP). Nutrient limitation is calculated as follows:

$$
f(N P)=\operatorname{Min}[f(N), f(P)]
$$

The preference of kelp for ammonium and nitrate is not considered in the model. Above a threshold level of N-quota, kelp growth increases with an increase of N-quota; below the threshold, growth did not occur. Following Ren et al. (2014), N-quotadependent growth is calculated as:

$$
f(N)=1-\frac{N_{\text {imin }}}{N_{\text {int }}}
$$

where $N_{\text {imin }}$ is the minimum internal cell quota for $\mathrm{N}$ and $N_{\text {int }}$ the internal content of $\mathrm{N}$ in kelp tissue. The relationship between macroalgal growth and P-quota is defined similarly (Ren et al. 2014):

$$
f(P)=1-\frac{P_{\text {imin }}}{P_{\text {int }}}
$$

where $P_{\text {imin }}$ is the minimum internal cell quota for $\mathrm{P}$ and $P_{\text {int }}$ is the internal $P$ concentration. Growth stops $(f(N)=0)$ when $N_{\text {int }}<N_{\text {imin }}$. Also, growth stops $(f(P)$ $=0)$ when $P_{\text {int }}<P_{\text {imin }}$. Variations in internal nutrient concentrations are determined by subtracting consumed nutrients $(\gamma)$ from the uptake of nutrients $(\Psi)$. The uptake of nutrients is described in Eq. 13, with the amount of consumed nutrients depending on macroalgal growth rate:

$$
\psi_{X}=\frac{X_{\text {imax }}-X_{\text {int }}}{X_{\text {imax }}-X_{\text {imin }}} \times V_{\max } \times \frac{X_{\text {ext }}}{K_{X}+X_{\text {ext }}}
$$

$\Psi_{X}$ is the nutrient $(X=\mathrm{N}$ or $\mathrm{P})$ uptake rate. The factor $\frac{X_{\text {ext }}}{K_{X}+X_{\text {ext }}}$ represents simple Michaelis-Menten kinetics (Holling 1959). $X_{\text {ext }}$ is the external nutrient con- centration (in water) and $X_{\text {int }}$ is the internal nutrient concentration (within the kelp tissue). $K_{X}$ is the halfsaturation constant for the uptake of the nutrient.

The factor $\frac{X_{\text {imax }}-X_{\text {int }}}{X_{\text {imax }}-X_{\text {imin }}}$ accounts for the internal nutrient reserve concentrations (Solidoro et al. 1997). $X_{\text {imax }}$ is the maximum internal concentration, $X_{\text {imin }}$ is the minimum internal concentration, and $V_{\max }$ is the maximum uptake rate of the nutrient. The use of internal nutrients is described as:

$$
\gamma_{\mathrm{X}}=X_{\text {int }} \times G_{\text {growth }}
$$

where $X_{\text {int }}$ is the internal nutrient concentration (within the plant).

\section{Model parameters}

Definitions and values of parameters used in the model are summarized in Table 1. The values for maximum $\mathrm{N}$ and $\mathrm{P}$ uptake rate were set to $V_{\operatorname{maxN}}=$ $60 \mu \mathrm{mol} \mathrm{gDW} \mathrm{gD}^{-1} \mathrm{~d}^{-1}$ and $V_{\max }=7 \mu \mathrm{mol} \mathrm{gDW}^{-1} \mathrm{~d}^{-1}$, respectively. Ozaki et al. (2001) report $V_{\operatorname{maxN}}$ for $S$. japonica to range from 0.54 to $1.95 \mu \mathrm{g} \mathrm{cm}^{-2} \mathrm{~h}^{-1}$, leading to 27.8-100 $\mathrm{mmol} \mathrm{gDW}^{-1} \mathrm{~d}^{-1}$, and $V_{\operatorname{maxP}}$ from 0.17 to $0.31 \mu \mathrm{g} \mathrm{cm}^{-2} \mathrm{~h}^{-1}$, leading to $3.95-7.2 \mu \mathrm{mol} \mathrm{gDW}{ }^{-1}$ $\mathrm{d}^{-1}$. Ozaki et al. (2001) reported $K_{\mathrm{N}}$ values ranging from 1.76 to $3.36 \mu \mathrm{mol} \mathrm{l^{-1 }}$, and a value of $3 \mu \mathrm{mol} \mathrm{l}^{-1}$ was chosen for our model. $N_{\text {imin }}$ and $N_{\text {imax }}$ were set to $500 \mu \mathrm{mol} \mathrm{gDW}^{-1}$ and $3000 \mu \mathrm{mol} \mathrm{gDW}^{-1}$, respectively (Chapman et al. 1978, Sjøtun 1993).

Our $P_{\text {imax }}$ and $P_{\text {imin }}$ values were set in accordance with the values of Mizuta et al. (2003). $K_{\mathrm{P}}$ was set to $0.1 \mu \mathrm{mol} \mathrm{l}^{-1}$ in our model, but data were limited. For brown macroalgae, the value of $K_{\mathrm{P}}$ varies from 0.14 to $11.17 \mathrm{\mu mol} \mathrm{l}^{-1}$ (Rees 2003). For Laminaria japonica (now Saccharina japonica), Ozaki et al. (2001) found $K_{\mathrm{P}}$ ranging from 0.09 to $0.18 \mu \mathrm{mol} \mathrm{l^{-1 }}$.

$I_{\mathrm{o}}$ was set to 180 , according to the experimental result by Zhu et al. (2004). S. japonica is usually cultured on ropes, with farmers adjusting culture depth as kelp weight increases. A depth of $0.2 \mathrm{~m}$ was set for $Z$. The temperature parameters $T_{\mathrm{e}}$ and $T_{\mathrm{opt}}$ were obtained from Petrell et al. (1993), Duarte et al. (2003) and Wu et al. (2009).

Chapman et al. (1978) reported the growth rate of the congeneric $S$. latissima (as Laminaria saccharina) to be $0.18 \mathrm{~d}^{-1}$. The maximum growth rate value in our model was set to $0.135 \mathrm{~d}^{-1}$, based on our own data (J. Zhang unpubl.). The values for $R_{\max 20}$ and $r$ were obtained from EPA (1985). Most algal models use empirical equations or set loss rates equal to some constant proportion of seaweed biomass, varying 
Table 1. Definitions and values of the parameters used in the kelp growth model. These are final values obtained by experimental procedure, field measurement, literature and/or calibration. DW: dry weight

\begin{tabular}{|c|c|c|c|c|}
\hline Symbo & Definition & Unit & Value & Source \\
\hline$R_{\max 20}$ & Maximum respiration rate at $20^{\circ} \mathrm{C}$ & $d^{-1}$ & 0.015 & EPA (1985) \\
\hline$r$ & Empirical coefficient & - & 1.07 & EPA (1985) \\
\hline$\mu_{\max }$ & Maximum growth rate & $d^{-1}$ & 0.135 & J. Zhang (unpubl.) \\
\hline$T_{\mathrm{opt}}$ & Optimum temperature for growth & ${ }^{\circ} \mathrm{C}$ & 13 & Petrell et al. (1993), Duarte et al. (2003) \\
\hline$T_{\max }$ & $\begin{array}{l}\text { Upper temperature limit above } \\
\text { which growth ceases }\end{array}$ & ${ }^{\circ} \mathrm{C}$ & 23 & Petrell et al. (1993) \\
\hline$I_{\mathrm{o}}$ & Optimum light intensity for growth & $\mathrm{W} \mathrm{m} \mathrm{m}^{-2}$ & 180 & Tseng (1981) \\
\hline$Z$ & Water depth of kelp mariculture & $\mathrm{m}$ & 0.2 & This study (adjusted to $0 \mathrm{~m}$ in the simulation) \\
\hline$N_{\text {imin }}$ & Minimum internal quota for nitrogen & $\mu \mathrm{mol} \mathrm{gDW} \mathrm{W}^{-1}$ & 500 & Chapman et al. (1978), Sjøtun (1993) \\
\hline$N_{\text {imax }}$ & Maximum internal quota for nitrogen & $\mu \mathrm{mol} \mathrm{gDW} \mathrm{W}^{-1}$ & 3000 & Chapman et al. (1978), Sjøtun (1993) \\
\hline$V_{\operatorname{maxN}}$ & Maximum nitrogen uptake rate & $\mu \mathrm{mol} \mathrm{gDW} \mathrm{g}^{-1} \mathrm{~d}^{-1}$ & 90 & Ozaki et al. (2001) \\
\hline$K_{\mathrm{N}}$ & $\begin{array}{l}\text { Half-saturation constant for nitrogen } \\
\text { uptake }\end{array}$ & $\mu \mathrm{mol} \mathrm{l} \mathrm{l}^{-1}$ & 2 & Ozaki et al. (2001), Shi et al. (2011) \\
\hline$P_{\text {imin }}$ & $\begin{array}{l}\text { Minimum internal phosphorus } \\
\text { concentration }\end{array}$ & $\mu \mathrm{mol} \mathrm{gDW} \mathrm{W}^{-1}$ & 31 & Mizuta et al. (2003) \\
\hline$P_{\text {imax }}$ & $\begin{array}{l}\text { Maximum internal phosphorus } \\
\text { concentration }\end{array}$ & $\mu \mathrm{mol} \mathrm{gDW} \mathrm{g}^{-1}$ & 250 & Mizuta et al. (2003) \\
\hline$K_{\mathrm{P}}$ & $\begin{array}{l}\text { Half-saturation constant for phosphate } \\
\text { uptake }\end{array}$ & $\mu \mathrm{mol} \mathrm{l} \mathrm{l}^{-1}$ & 0.1 & Ozaki et al. (2001), Kitadai \& Kadowaki (2003) \\
\hline$V_{\operatorname{maxP}}$ & Maximum phosphate uptake rate & $\mu \mathrm{mol} \mathrm{ngDW} \mathrm{W}^{-1} \mathrm{~d}^{-1}$ & 7 & Kitadai \& Kadowaki (2003) \\
\hline ER & Individual erosion rate & $d^{-1}$ & $\begin{array}{c}0.01 \% \text { (day } 130) \\
0.015 \% \text { (days } \\
130-180)\end{array}$ & This study (adjusted) \\
\hline
\end{tabular}

from 0.0005 to $0.03 \mathrm{~d}^{-1}$ (Canale \& Auer 1982). With the hole-punching method, Suzuki et al. (2008) measured an erosion rate of $S$. japonica in the range of $0.3-2.3 \mathrm{~g}$ wet weight $\mathrm{d}^{-1}$, which corresponds to $1.8-4 \% \mathrm{~d}^{-1}$. As temperature increases, rates of erosion of more mature plants also increase. For our simulations, we adjusted ER to 0 for simulation days $0-128,0.01 \% \mathrm{~d}^{-1}$ for day 130 , and $0.015 \% \mathrm{~d}^{-1}$ for days $130-180$.

\section{Calibration, validation and statistical analysis}

Model calibration was conducted using data from the 2011-2012 culture cycle, whereas data from the 2008-2009 culture cycle was used for validation. The goodness-of-fit of model performance was evaluated by linear regression between the observation (on the $x$-axis) and simulation (on the $y$-axis), which was tested against the model $y=x$. Limiting factors for growth depended on $f(T), f(I)$ and $f(N P)$, being functions with normalized values between 0 (maximum limitation) and 1 (no limitation).

Following Majkowski (1982) and Ren et al. (2014), we performed sensitivity analyses to assess the responses of the model to changes in model parameters. For each model run, 1 parameter was changed by $\pm 10 \%$ (for temperature this is equivalent to a $\pm 3^{\circ} \mathrm{C}$ shift), and the relative change in model output was used to calculate sensitivity. The difference $(S)$ between the unperturbed and perturbed results from the model was measured by:

$$
S=\frac{1}{n} \sum \frac{x_{i, t}-x_{t}^{0}}{x_{t}^{0}}
$$

where $n$ is the number of simulation days, $x_{t}^{0}$ is the individual dry weight of kelp predicted with the calibrated set of parameters set at time $t$, and $x_{i, t}$ is the individual mass with 1 perturbed parameter of $i$ at time $t$. Two model runs were performed for each parameter, differing by $\pm 10 \%$. The averaged percentage change in individual dry weight from the 2 model runs was used as a measure of sensitivity of the change in the parameter value.

\section{RESULTS}

Fig. 3 shows the environmental data collected during 2008-2009 and 2011-2012. Temperature and nutrient data from November were used for initial model conditions.

During model calibration (using 2011-2012 data), reasonable agreement was achieved between the modelled and observed dry weight of kelp (Fig. 4A), and during validation, simulated DW also matched observed data with significant linear correlation $\left(\mathrm{R}^{2}=0.969\right.$; ANOVA, $\mathrm{p}<0.001$ ) (Fig. 4B). 

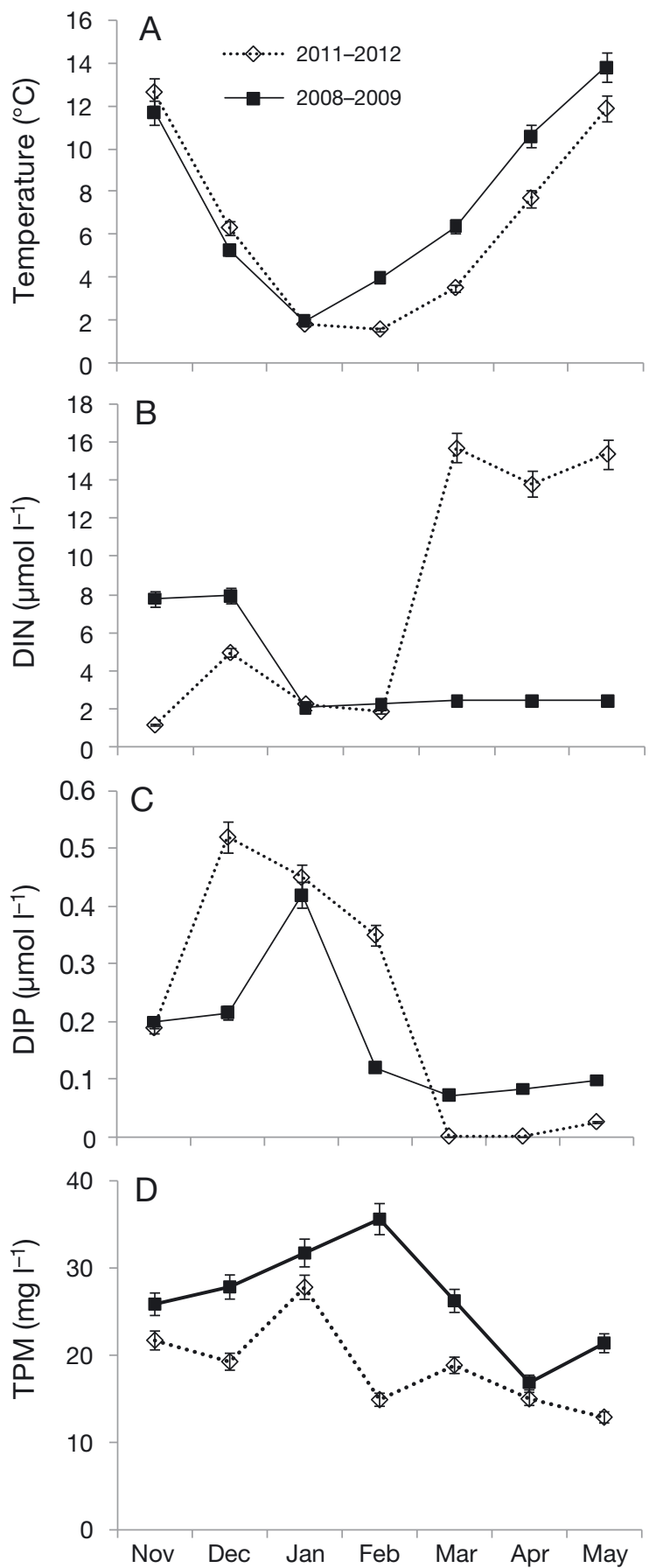

Fig. 3. Observed environmental data (mean $\pm \mathrm{SE}$ ) for the periods 2008-2009 and 2011-2012 in Sanggou Bay, China, that were used to force the kelp growth model. (A) Temperature, (B) dissolved inorganic nitrogen (DIN), (C) dissolved inorganic phosphorus (DIP), and (D) total suspended particulate materials (TPM)

The simulated and observed values for 2011-2012 and for 2008-2009 were plotted in Fig. 5. For 2001-2012, $y=x$ regression of the data revealed a significant correlation $\left(\mathrm{R}^{2}=0.996\right.$; ANOVA, $\left.\mathrm{p}<0.001\right)$.
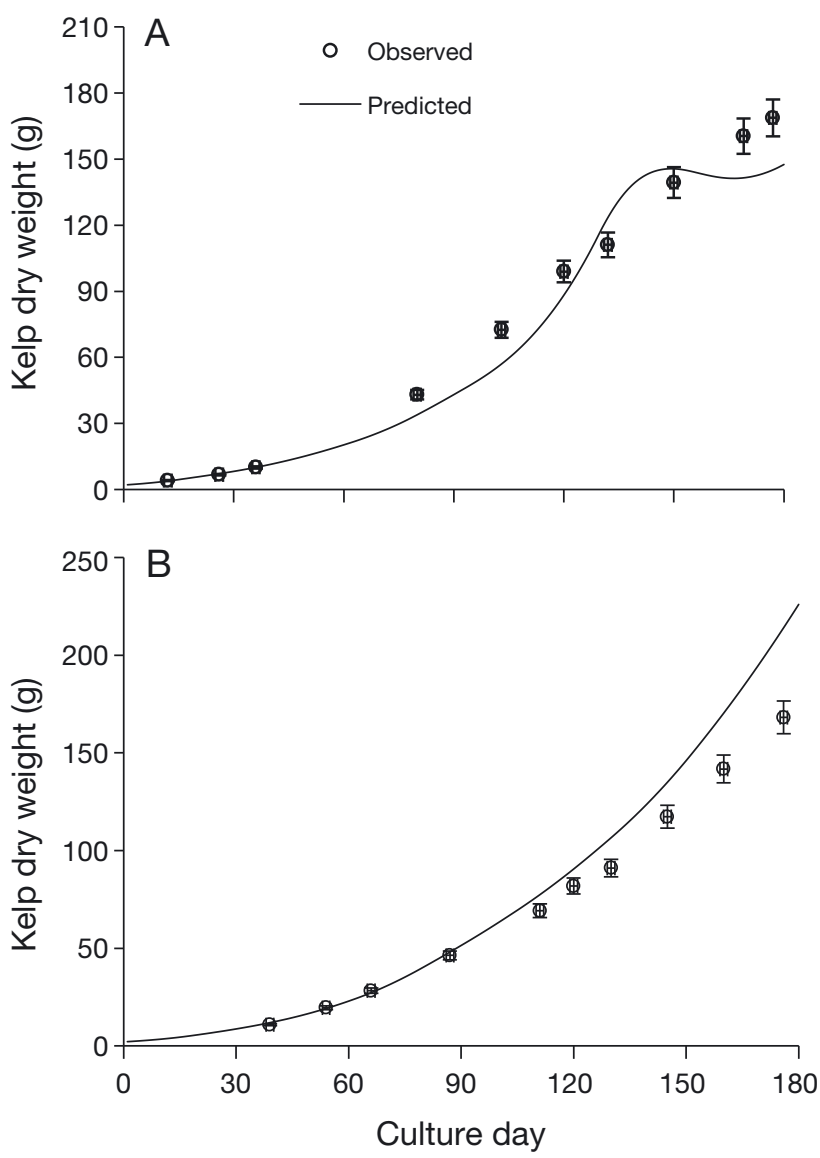

Fig. 4. Comparison of measured and predicted individual dry weight (mean $\pm \mathrm{SE}$ ) of cultured kelp Saccharina japonica in Sanggou Bay, China. (A) 2011-2012, (B) 2008-2009

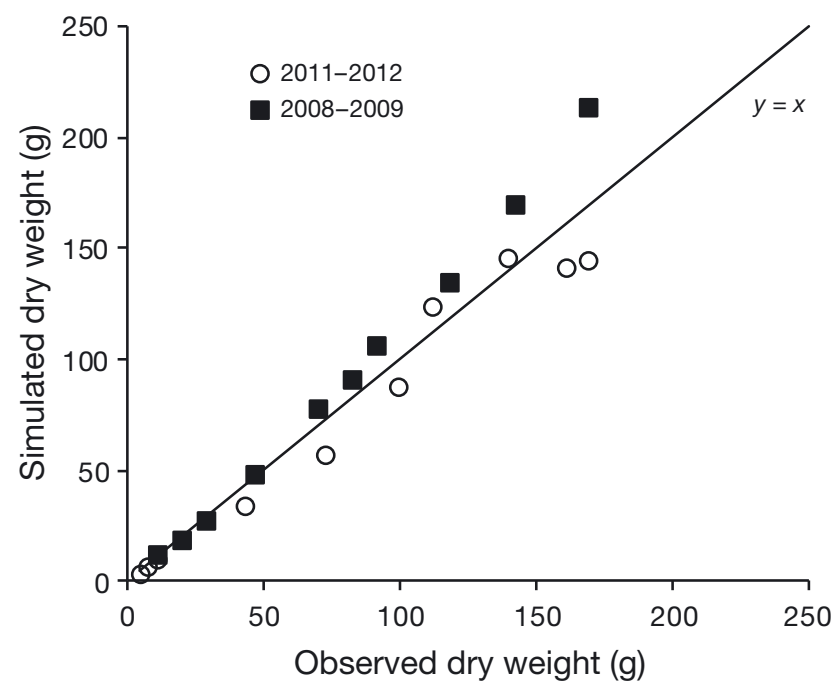

Fig. 5. Observed individual dry weight of cultured kelp vs. values simulated by the kelp growth model for the periods 2011-2012 $\left(\mathrm{R}^{2}=0.995, \mathrm{p}<0.001\right)$ and 2008-2009 $\left(\mathrm{R}^{2}=\right.$ $0.969, p<0.001)$. For a perfect fit all points would be on the line $y=x$ 
Statistical analysis showed that predicted values did not significantly differ from observed values (ANOVA, $\mathrm{p}>0.64$ ). In addition, the model achieved a reasonably low root mean square error $(\mathrm{RMSD}=12.4)$. For 2008-2009, there was no significant difference between prediction and observation $(\mathrm{RMSD}=19.0$; ANOVA, $p>0.65$ ). The model satisfactorily reproduced the growth of kelp in both years, but achieved a much better result for the period 2011-2012 than 2008-2009.

The effects of nutrients, light intensity and temperature on growth are shown in Fig. 6, plotting normalized functions of these parameters $(0=$ maximum limitation, $1=$ no limitation). During the culture cycle (November-May), nutrients were the greatest limiting factor in kelp growth, while there was also substantial light and temperature limitation. The values of $f(N P)$ varied between 0.15 and 0.5 in 2011-2012, and 0.30-0.54 in 2008-2009, with the lowest value on simulation days 150-180 (from mid-March to late April). For $f(I)$ and $f(T)$, the values ranged from $0.66-0.99$ and $0.78-1.0$, respectively, both with the lowest value on simulation day 60 (the beginning of January).
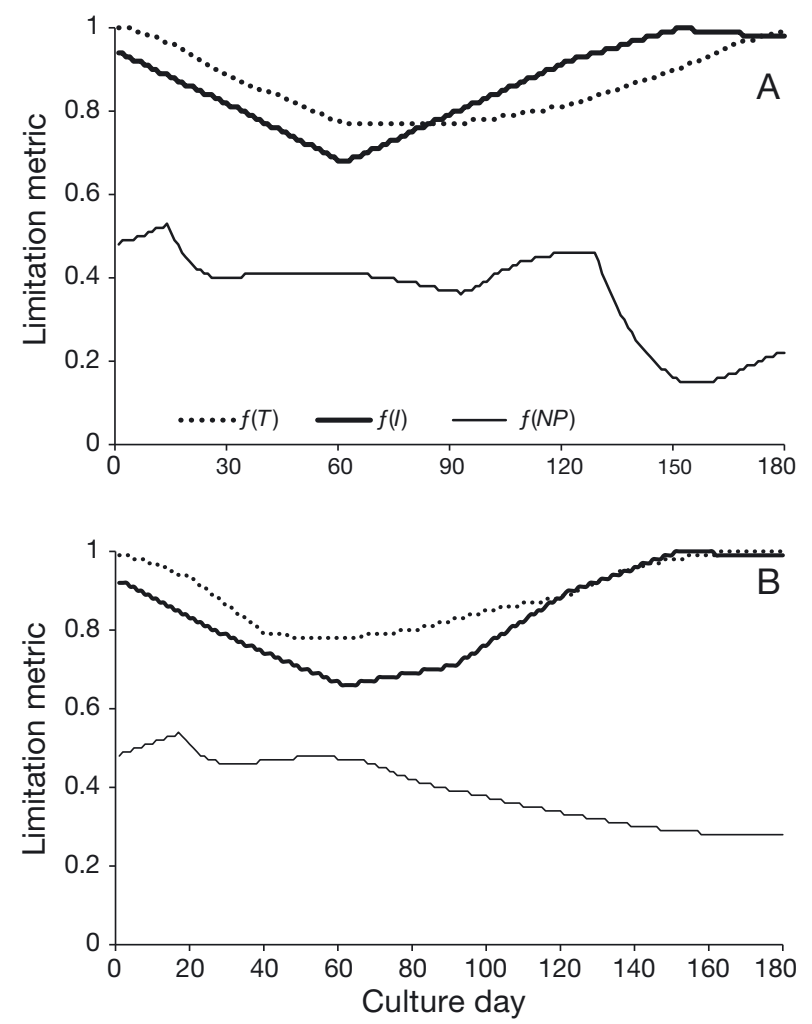

Fig. 6. Comparison among environmental limitation factors for temperature $(T)$, irradiance $(I)$ and nutrients (dissolved inorganic nitrogen or phosphorus; $N P$ ) on the growth of cultured kelp Saccharina japonica. Results of normalized functions over time are shown; a value close to 1 indicates the absence of limitation. (A) 2011-2012, (B) 2008-2009
The effects of $\mathrm{N}$ and $\mathrm{P}$ limitation on growth are shown in Fig. 7. At simulation days 15-130 in 20112012, $f(N)$ values were lower than $f(P)$ values, whereas $f(P)$ values were lower than $f(N)$ values on days 130-180 (Fig. 7A). While in 2008-2009, the values of $f(N)$ were lower than $f(P)$ from days 15-180 (Fig. 7B).

Sensitivity analysis revealed that the model is relatively sensitive to changes in most model parameters (Table 2). $S$ was $<100 \%$ in all cases tested, suggesting that uncertainties in parameters and initial conditions are not amplified in the values of the state variables. The empirical coefficient of respiration $(r)$ was found to exert the greatest influence on the prediction result of the model, in which $10 \%$ change resulted in an extensive change in model output $(89.45 \%)$. Other relatively sensitive parameters were the maximum growth rate $\left(\mu_{\max }\right)$ and the minimum internal quota for nitrogen $\left(N_{\text {imin }}\right)$.

The simulations of unlimited nutrient supply showed that in 2011-2012, assuming $f(N)=1$, DW of kelp increased 3.4 times, and $f(P)=1$, DW of kelp increased 3.0 times (Fig. 8A). However, in 2008-2009, only fertilization with $\mathrm{N}$ resulted in an increase in kelp growth (Fig. 8B). Raising the culture
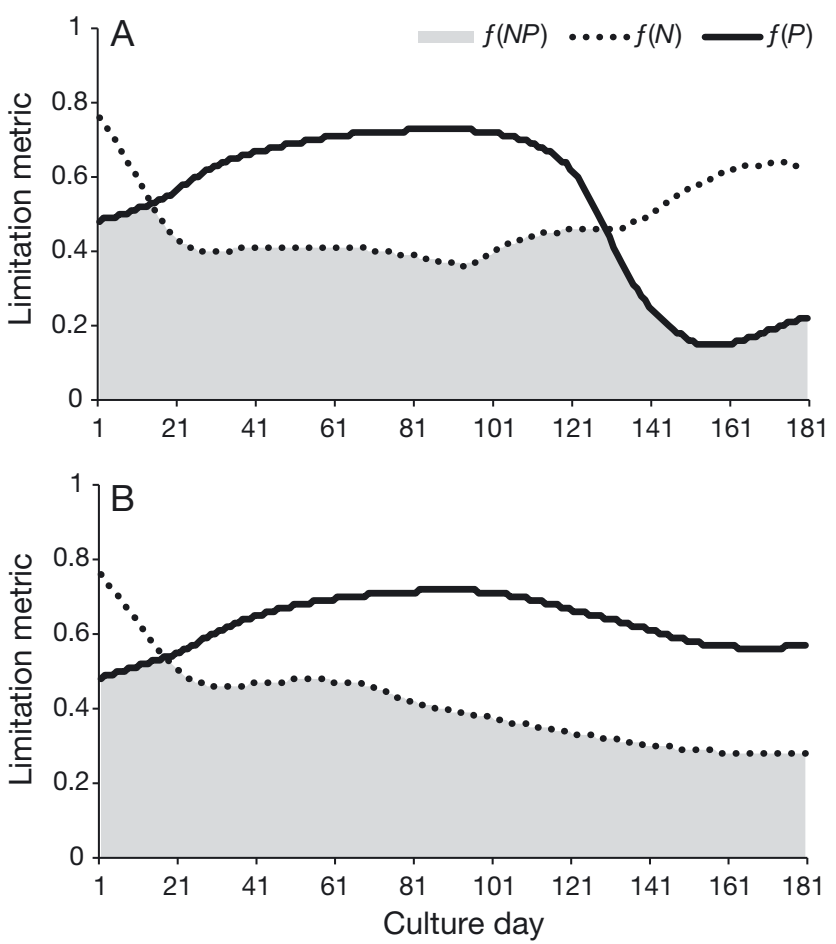

Fig. 7. Nutrient limitation factors on the growth of cultured kelp Saccharina japonica. Results of normalized functions for the concentration of dissolved inorganic nitrogen $(N)$, phophorus $(P)$ or both ( $N P$, grey shaded area) over time are shown; a value close to the gray shaded area indicates growth limitation. (A) 2011-2012, (B) 2008-2009 
Table 2. Sensitivity analyses as percent relative change from the baseline of dry weight of cultured Saccharina japonica predicted by the kelp growth model after changing each model parameter by $\pm 10 \%$ (except $T_{\min }$ changed only $+10 \%$ from standard value of $T_{\min }=0.5^{\circ} \mathrm{C}$ ). Parameters with very low sensitivity coefficients $(<1 \%)$ are not presented. See Table 1 for parameter definitions

\begin{tabular}{|cc|}
\hline Model parameter & \% change \\
\hline$r$ & 89.45 \\
$\mu_{\max }$ & 25.97 \\
$N_{\text {imin }}$ & 18.05 \\
$V_{\max }$ & 15.41 \\
$T_{\text {opt }}$ & 14.93 \\
$P_{\min }$ & 14.57 \\
$V_{\operatorname{maxP}}$ & 12.75 \\
$R_{\max 20}$ & 7.90 \\
$K_{\mathrm{N}}$ & 5.75 \\
$K_{\mathrm{P}}$ & 6.57 \\
$P_{\operatorname{imax}}$ & 3.52 \\
$N_{\text {imax }}$ & 3.33 \\
$I_{\mathrm{o}}$ & 1.37 \\
\hline
\end{tabular}

ropes from $0.2 \mathrm{~m}$ depth up to the surface would result in the final DW of kelp being increased by $18.8 \%$ in 2011-2012 (Fig. 9).

\section{DISCUSSION}

The kelp growth model reflects the relationship between productivity and the environment. It is a useful tool for the management of kelp mariculture.

\section{Temperature}

Recent research has focused on the influence of increased seawater temperature on the growth of Saccharina japonica in cold-water environments (Ohno \& Matsuoka 1992, Suzuki et al. 2006). The influence of low temperature on kelp growth is not being concerned about: However, from this study, we found that the growth of $S$. japonica in Sanggou Bay was largely limited by temperature, particularly during culture days 60-120 in January-February. A previous study showed that the uptake rates of nitrate and phosphate by $S$. japonica decreased when water temperature dropped to $<5^{\circ} \mathrm{C}$ (Ozaki et al. 2001). In Sanggou Bay in 2011-2012, water temperature fell $<5^{\circ} \mathrm{C}$ for over 2 mo in winter and became the main limiting factor for $S$. japonica growth in this season.

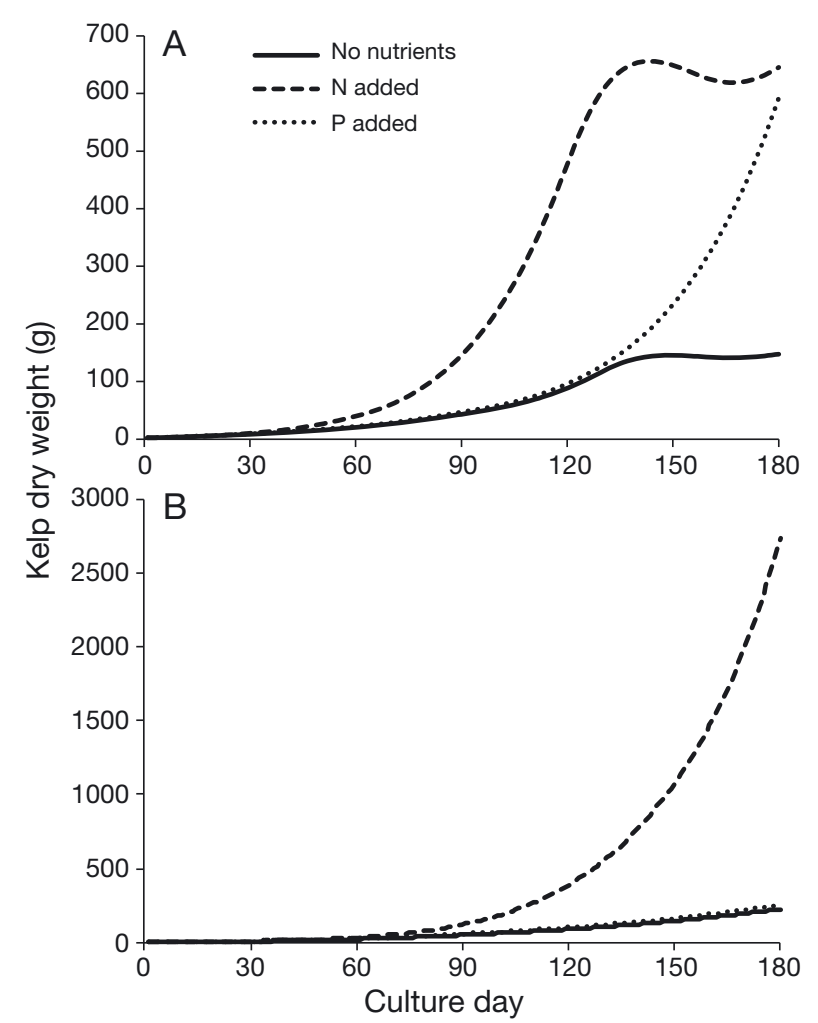

Fig. 8. Simulation results on the potential effect of fertilization with dissolved inorganic nitrogen $(\mathrm{N})$ or phosphorus $(\mathrm{P})$ on the individual dry weight of cultured kelp Saccharina japonica in comparison to predicted growth without fertilization. Addition of nutrients to fertilize kelp was implemented by running the model with the normalized functions of $\mathrm{N}$ and $\mathrm{P}$ set to 1 (i.e. absence of nutrient limitation). (A) 2011-2012, (B) 2008-2009

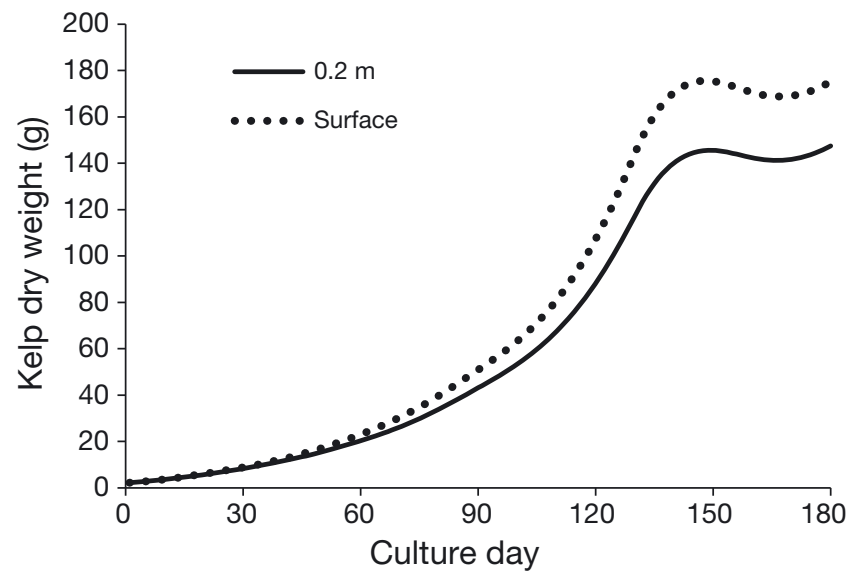

Fig. 9. Simulated growth (individual dry weight) of kelp Saccharina japonica when lifting the culture ropes from $0.2 \mathrm{~m}$ depth to the surface

\section{Light}

The surface radiation and extinction of light in the water column affect the light intensity available to kelp. Although clouds and dust in the atmosphere 
could influence the incident surface radiation to some extent, there is considerable variation in the incident surface radiation with geographical position. Our results showed that although kelp was cultured near the water surface in Sanggou Bay, light intensity was still a limiting factor in winter (Fig. 9). Extinction of light depends on depth and suspended particles in the water. Despite diurnal and seasonal variations of the light extinction coefficient $(k)$, the use of total suspended particulate materials to calculate $k$ still achieved reasonable results. In addition, self-shading by macroalgal thalli can also affect $k$. However, most reports were on natural macroalgae, such as Ulva, where the density of a natural population is not uniform and can be very high (e.g. Enriquez et al. 1994, Ren et al. 2014). In maricultural macroalgae, density is controlled. The suspended long-line culture usually allows the kelp fronds to float horizontally, which reduces self-shading. Therefore, in the model, we did not consider the influence of self-shading on the growth of kelp.

Earlier types of models to assess the carrying capacity for kelp (Shi et al. 2011) or for multi-species (kelp and scallop) culture in Sanggou Bay (Duarte et al. 2003) do not consider light to be a limiting factor, because the depth of kelp culture ropes was manually adjusted to overcome light limitation in the past. As kelp weight increases, the culture rope is submerged under water. Farmers adjust the depth of culture ropes by increasing or decreasing the number of floating balls. However, with increasing scale and labor costs of present-day mariculture, this practice is no longer feasible considering the economic value of kelp, although our model shows that the DW of kelp could theoretically be increased by $18 \%$ with raising culture ropes to the surface when light is limited.

\section{Nutrients}

The availability of nutrients is one of the primary factors regulating macroalgae growth in a marine ecosystem. In this study, we identified nutrient availability to be the key limiting factor for kelp growth and there were seasonal and inter-annual variations of limitations in $\mathrm{N}$ or $\mathrm{P}$. $\mathrm{N}$ was the main limiting factor in the culture period 2008-2009 and on simulation days 15-130 in 2011-2012. The kelp farming area is not only in the middle area of the bay, but also has been expanded to the mouth and even outside the bay. Therefore, both the rafts and seaweeds impede water exchange of the bay with the Yellow Sea, which limits influx of supplementary oceanic nutrients. Coupled with the absorption of nutrients by seaweed and little riverine input, nutrient concentrations within Sanggou Bay are usually lower during the kelp cultural season than during the rest of the year (Liu et al. 2003, Sun et al. 2007, Zhang et al. 2011). Consequently, variability in nutrient availability can strongly influence kelp productivity (Rosell \& Srivastava 1984, Ahn et al. 1998). In the past, farmers have increased mariculture seaweed yield by fertilizing them with ammonia or urea. On the northern coast of China, Tseng et al. (1955) conducted experiments to investigate the effect of fertilizer application on the growth of $S$. japonica, and found that the harvest could be increased by 3 to 4 times with increasing the DIN concentration. Our model simulations also showed that kelp DW could be increased by 3.4 times in the absence of $\mathrm{N}$ limitation. Although the application of nitrogen fertilizers can increase the yield of kelp, few farmers in Sanggou Bay fertilize with N during the kelp culture period.

Recent studies have shown that phosphates and silicates can become limiting factors for phytoplankton growth in Sanggou Bay (Quet al. 2008, Zhang et al. 2011). However, there are no reports on the influence of phosphates on kelp mariculture. Our results revealed that low $\mathrm{P}$ availability was a key limiting factor for kelp growth only on simulation days 130-180 in 2011-2012. As one of few studies reporting on the relationship between $\mathrm{P}$ availability and macroalgal growth, Lapointe et al. (1992) found that low availability of $\mathrm{P}$ limited macroalgal productivity in oligotrophic waters. Although Sanggou Bay is not known to be oligotrophic, the concentrations of phosphate became too low to support potential growth during March to May in 2012 (Fig. 3). According to our model, enriching waters with phosphates could have improved kelp growth in 2012, but not in 2009 . Therefore, whether to fertilize or not and at which seasons depends on the specific circumstances of the environment in a particular year.

The addition of nutrients may improve kelp growth, but it may also cause potentially detrimental ecological responses. Nutrient addition can stimulate the growth of phytoplankton and other macroalgae, increasing the competition for nutrients and causing light limitation; effects that, in concert, could cause more serious ecological problems, such as the formation of red tides.

IMTA is a form of ecological engineering that combines the biological processes of cultured fish and extractive co-cultured species to remove waste loadings associated with intensive aquaculture systems 
(Troell et al. 2009). Co-cultures of macroalgae have been successfully used to reduce the amount of aquaculture-derived inorganic nutrients (Yu et al. 2014). Similarly, the IMTA practice could stimulate the growth of kelp, because the release of aquaculture-derived inorganic nutrients is equivalent to kelp fertilization. In view of the observed nutrient limitation in Sanggou Bay, the results of the present modelling study indicate that the introduction of cage culture (in which fish are fed highly nutritious food, resulting in soluble waste materials containing ammonium and soluble P) would be beneficial for kelp growth (Ahn et al. 1998).

Acknowledgements. The study was supported by the National Science and Technology Pillar Program (no. 2011BAD13B06), National Natural Science Foundation of China (no. 41276172), and Special Fund of Basic Research for Central non-profit Scientific Research Institute (no. 2014A01YY01). We thank Mr. Huayao Zhang from Xunshan Fisheries Group for his help in measuring the growth of Saccharina japonica.

\section{LITERATURE CITED}

Ahn O, Petrell RJ, Harrison PJ (1998) Ammonium and nitrate uptake by Laminaria saccharina and Nereocystis luetkeana originating from a salmon sea cage farm. J Appl Phycol 10:333-340

Aveytua-Alcázar L, Camacho-Ibar VF, Souza AL, Allen JI, Torres R (2008) Modelling Zoestra marina and Ulva spp. in a coastal lagoon. Ecol Modell 218:354-366

Buschmann AH, Varela DA, Hernández-González MC, Huovinen P (2008) Opportunities and challenges for the development of an integrated seaweed-based aquaculture activity in Chile: determining the physiological capabilities of Macrocystis and Gracilaria as biofilters. J Appl Phycol 20:571-577

Canale RP, Auer MT (1982) Ecological studies and mathematical modeling of Cladophora in Lake Huron: V. Model development and calibration. J Gt Lakes Res 8: $112-125$

> Chapman ARO, Craigie JS (1977) Seasonal growth in Laminaria longicruris-relations with dissolved inorganic nutrients and internal reserves of nitrogen. Mar Biol 40: 197-205

Chapman ARO, Marklam JW, Luning K (1978) Effect of nitrate concentration on the growth and physiology of Laminaria saccharina in culture. J Phycol 14:195-198

Chopin T, Buschmann AH, Halling C, Troell M and others (2001) Integrating seaweeds into marine aquaculture systems: a key toward sustainability. J Phycol 37:975-986

> Duarte P, Ferreira JG (1997) A model for the simulation of macroalgal population dynamics and productivity. Ecol Modell 98:199-214

> Duarte R, Meneses R, Hawkins AJS, Zhu M, Fang JG, Grant $\mathrm{J}$ (2003) Mathematical modelling to assess the carrying capacity for multi-species culture within coastal waters. Ecol Modell 168:109-143

Enriquez S, Agustí S, Duarte C (1994) Light absorption by marine macrophytes. Oecologia 98:121-129

EPA (Environmental Protection Agency) (1985) Rates, constants, and kinetics. In: Bowie GL, Mills WM, Porcellaet DB, Campbell CL and others (eds) Formulations in surface water quality modelling, 2nd edn. EPA, Atlanta, GA, p 188-204

FAO (Food and Agriculture Organization of the United Nations) (2014) Global Aquaculture Production 19502014 database. http://www.fao.org/fishery/statistics/ global-aquaculture-production/query/en

Fei XG (2004) Solving the coastal eutrophication problem by large scale seaweed cultivation. Hydrobiologia 512: 145-151

Grasshoff K, Ehrhardt M, Kremling K (eds) (1983) Methods of seawater analysis. Verlag Chemie, Weinheim

Holling CS (1959) Some characteristics of simple types of predation and parasitism. Can Entomol 91:385-398

Kitadai Y, Kadowaki S (2003) The growth process and N, P uptake rates of Laminaria japonica cultured in coastal fish farms. Aquacult Sci 51:15-23

Lapointe BE, Littler MM, Littler DS (1992) Nutrient availability to marine macroalgae in siliclastic versus carbonate-richcoastal waters. Estuaries 15:75-82

Li L, Ren JL, Liu SM, Jiang ZJ, Du JZ, Fang JG (2014) Distribution, seasonal variation and influence factors of dissolved inorganic arsenic in the Sanggou Bay. Huan Jing Ke Xue 35:2705-2713 (in Chinese with English abstract)

> Liu H, Fang JG, Dong SL, Wang LC, Lian Y (2003) Annual variation of major nutrients and limiting factors in Laizhou Bay and Sanggou Bay. J Fish Sci China 10: 227-234 (in Chinese with English abstract)

Liu Y, Saitoh SI, Radiarta IN, Isada T, Hirawake T, Mizuta H (2013) Improvement of an aquaculture site-selection model for Japanese kelp (Saccharina japonica) in southern Hokkaido, Japan: an application for the impacts of climate events. ICES J Mar Sci 70:1460-1470

Majkowski J (1982) Usefulness and applicability of sensitivity analysis in a multispecies approach to fisheries management. In: Pauly D, Murphy GI (eds) Theory and management of tropical fisheries. ICLARM Conf Proc 9: 149-165

- Martins I, Marques JC (2002) A model for the growth of opportunistic macroalgae (Enteromorpha sp.) in tidal estuaries. Estuar Coast Shelf Sci 55:247-257

> Mizuta H, Ogawa S, Yasui H (2003) Phosphorus requirement of the sporophyte of Laminaria japonica (Phaeophyceae). Aquat Bot 76:117-126

> Nunes JP, Ferreira JG, Gazeau F, Lencart-Silva J, Zhang XL, Zhu MY, Fang JG (2003) A model for sustainable management of shellfish polyculture in coastal bays. Aquaculture 219:257-277

Ohno M, Matsuoka M (1992) Growth of cultivated Laminaria japonica, Undaria pinnatifida, and U. undarioides in sub-tropical waters of Tosa Bay. Aquacult Sci 40: 279-283 (in Japanese with English abstract)

> Ozaki AI, Mizuta H, Yamamoto H (2001) Physiological differences between the nutrient uptakes of Kjellmaniella crassifolia and Laminaria japonica (Phaeophyceae). Fish Sci 67:415-419

Parsons TR, Takahashi M, Hargrave B (eds) (1984) Biological oceanographic processes. Pergamon Press, New York, NY

Pedersen MF, Borum J (1996) Nutrient control of algal growth in estuarine waters. Nutrient limitation and the importance of nitrogen requirements and nitrogen 
storage among phytoplankton and species of macroalgae. Mar Ecol Prog Ser 142:261-272

Petrell RJ, Tabrizi KM, Harrison PJ, Druehl LD (1993) Mathematical model of Laminaria production near a British Columbian salmon sea cage farm. J Appl Phycol 5:1-14

Qu KM, Song YL, Xun Y, Fang JG (2008) Experiment on nutrient limitations in cultured areas of Sanggou Bay in situ in spring and summer. Mar Environ Sci 27:124-127 (in Chinese with English abstract)

Rees TAV (2003) Safety factors and nutrient uptake by seaweeds. Mar Ecol Prog Ser 263:29-42

Ren JS, Barr NG, Scheuer K, Schiel DR, Zeldis J (2014) A dynamic growth model of macroalgae: application in an estuary recovering from treated wastewater and earthquake-driven eutrophication. Estuar Coast Shelf Sci 148: 59-69

Rosell KG, Srivastava LM (1984) Seasonal variation in the chemical constituents of the brown algae Macrocystis integrifolia and Nereocystis luetkeana. Can J Bot 62: 2229-2236

Shi J, Wei H, Zhao L, Yuan Y, Fang JG, Zhang JH (2011) A physical-biological coupled aquaculture model for a suspended aquaculture area of China. Aquaculture 318: 412-424

Sjøtun K (1993) Seasonal lamina growth in two age groups of Laminaria saccharina (L.) Lamour. in western Norway. Bot Mar 36:433-441

Solidoro C, Pecenik G, Pastres R, Franco D, Dejak C (1997) Modelling macroalgae (Ulvarigida) in the Venice Lagoon: model structure identification and first parameters estimation. Ecol Modell 94:191-206

Sun PX, Zhang ZH, Hao LH, Wang B and others (2007) Analysis of nutrient distributions and potential eutrophication in seawater of the Sanggou Bay. Adv Mar Sci 25: 436-445 (in Chinese with English abstract)

Suzuki S, Furuya K, Takeuchi I (2006) Growth and annual

Editorial responsibility: Sebastien Lefebvre (Guest Editor), Wimereux, France production of the brown alga Laminaria japonica (Phaeophyta, Laminariales) introduced into the Uwa Sea in southern Japan. J Mar Biol Assoc UK 339:15-29

Suzuki S, Furuya K, Kawai T, Takeuchi I (2008) Effect of seawater temperature on the productivity of Laminaria japonica in the Uwa Sea, southern Japan. J Appl Phycol 20:833-844

Troell M, Halling C, Neori A, Chopin T, Buschmann AH, Kautsky N, Yarish C (2003) Integrated mariculture: asking the right questions. Aquaculture 226:69-90

Troell M, Joyce A, Chopin T, Neori A, Buschmann AH, Fang JG (2009) Ecological engineering in aquaculture-potential for integrated multi-trophic aquaculture (IMTA) in marine offshore systems. Aquaculture 297:1-9

Tseng CK, Sun KY, Wu CY (1955) Studies on fertilizer application in the cultivation of Haitai (Laminaria japonica Areseh). Acta Bot Sin 4:374-392 (in Chinese with English abstract)

Tseng CK (1981) Commercial cultivation. In: Lobban CS, Wynne MJ (eds) The biology of seaweeds. University of California Press, Berkeley, CA, p 680-725

- Wu RJ, Zhang XL, Zhu MY, Zheng YF (2009) A model for the growth of Haidai (Laminaria japonica) in aquaculture. Mar Sci Bull 28:34-40 (in Chinese with English abstract)

> Yu Z, Zhu X, Jiang Y, Luo P, Hu C (2014) Bioremediation and fodder potentials of two Sargassum spp. in coastal waters of Shenzhen, South China. Mar Pollut Bull 85: 797-802

Zhang JH, Ren LH, Xu D, Zhang ML and others (2011) Analysis of water quality of abalone suspended long-line mariculture area of Sanggou Bay. J Fish Sci China 35: 52-58 (in Chinese with English abstract)

> Zhu MY, Wu RJ, Li RX, Yue GF, Sun PX, Deslous-Paoli JM, Auby I (2004) The impacts of temperature on growth and photosynthesis of Laminaria japonica juvenile sporophytes. Acta Ecol Sin 24:22-27

Submitted: June 1, 2015; Accepted: January 22, 2016

Proofs received from author(s): April 5, 2016 